\title{
Political Mobilisation of Religious, Chauvinist, and Technocratic Populists in Indonesia and Their Activities in Cyberspace
}

\author{
Ihsan Yilmaz * (D) and Greg Barton
}

Citation: Yilmaz, Ihsan, and Greg Barton. 2021. Political Mobilisation of Religious, Chauvinist, and

Technocratic Populists in Indonesia and Their Activities in Cyberspace. Religions 12: 822. https://doi.org/ $10.3390 /$ rel12100822

Academic Editors: Franz Winter and Jocelyne Cesari

Received: 31 August 2021

Accepted: 22 September 2021

Published: 1 October 2021

Publisher's Note: MDPI stays neutral with regard to jurisdictional claims in published maps and institutional affiliations.

Copyright: (C) 2021 by the authors Licensee MDPI, Basel, Switzerland. This article is an open access article distributed under the terms and conditions of the Creative Commons Attribution (CC BY) license (https:// creativecommons.org/licenses/by/ $4.0 /)$
Alfred Deakin Institute for Citizenship and Globalization, Deakin University, Melbourne, VIC 3125, Australia; greg.barton@deakin.edu.au

* Correspondence: ihsan.yilmaz@deakin.edu.au

\begin{abstract}
Populism has been on the rise in many countries. As a result, studies on populism have proliferated. However, there are very few studies that investigate and compare different types of populisms in a single nation-state. Furthermore, how these different populists in the same political milieu use cyberspace has not been comparatively studied. This study addresses these gaps by looking at a variety of populist forces within Indonesia that have emerged as major actors and identifying the uses of cyberspace in populist political mobilisation. This paper argues that the three main types of populism that predominate in political rhetoric (religious, chauvinistic, and technocratic) do not exist in isolation but rather borrow from each other. This is reflected in their cyberspace activities.
\end{abstract}

Keywords: populism; religious populism; technocratic populism; chauvinistic populism; Indonesia; social media

\section{Introduction}

In a sense, when religious individuals or groups use social media, it is not only for their online presence or preaching; rather, there is a mediation of meaning that takes place where religious ideas and belief systems are exchanged and discussed actively by users (Siuda 2021; Hoover 2006). With the advent of social media sites such as Instagram, Twitter, TikTok, Facebook, SnapChat, etc. there is a growing agency on the user's end to interact with the materials; Siuda (2021) calls the internet a growing space where religion has an "important role to play in negotiating and expressing beliefs as well" (Siuda 2021).

Even traditional religions such as Islam and Christianity have found a space for reinvention and expression in cyberspace. This means that in the online space, religion also finds itself being mixed up with populist politics. In the 1990s and even more so in the 2000s, the internet was seen as an ideal tool for globalisation and connectivity. However, this somewhat untarnished reputation is now clouded by issues such as fake news and propagation of xenophobia and hate speech (Bartlett 2018; Levinson 2020). Cyberspace is inseparable from the social and political realities of real life and in many ways mirrors those rifts.

Conventional media, and now increasingly social media, in Indonesia have played profound roles in creating moral panic and anxiety around the idea that one's identity is under existential attack. Indonesian "voters strongly believing in pluralism or Islamism are most fraught with notions that their identity is under attack, and they flocked to either Jokowi or Prabowo and the Islamists to defend those identities" (Mietzner 2020, p. 433).

Unfulfilled dreams and unsatisfied demands have seen a discourse of dissatisfaction gathering force that has been capitalised by the populists or leading populist politics to shape the political landscape in Indonesia. In this context, where the political leadership and opposition have both used populism, other groups have also profited from the growing 
susceptibility of populism in society. The growth of internet usage has meant that Islam and politics have found themselves on various digital platforms in cyberspace. Within cyberspace, as in the physical world, various groups have found a voice. While there is a substantial increase in online presence, this has meant that religion, populism, and a merger of both have also been present on these platforms used by politicians, religious leaders, and citizens alike to at times research political goals or make sense of their identity and belief systems.

This study focusses on this critical political junction of Indonesian politics to study the variety of political populist spectrums by looking at the existing literature and understanding the main populist actors, their strategies, and their activities in cyberspace. It addresses the need to provide a comprehensive account of populist leaders and parties within Indonesia along with their use of social media.

\section{Populism and Its Use of Cyberspace}

A systematic review of populism shows that the concept emerged as a way of framing the struggle of the 'common person' against the 'elite' and that this axial dichotomy has evolved under a variety of political circumstances since its emergence (Yilmaz and Morieson 2021). One of the earliest academic investigations into the phenomenon by the sociologist Edward Shils led to its definitional parameters being summed up as the following: "popular resentment against the order imposed on society by a ... ruling class which is believed to have a monopoly on power, property, breeding, and culture" (Shils 1956, pp. 100-1). Whilst the rise in populism around the world today has seen a significant surge in academic interest in the topic, as yet no singular definition of populism has been agreed upon. Nevertheless, Shil's axial notion of "popular resentment" posed against "the order" has advanced to become broadly accepted as the defining paradigm of populism.

One of the most common approaches to understanding and defining populism is the ideological approach (De la Torre 2019; Mudde 2004). This approach argues that populism's divisional politics centre around ideological approaches that are used by the party/leader to forge a shared ideology with 'the people.' Mudde (2004, p. 543) asserts that this approach in politics "considers society to be ultimately separated into two homogenous and antagonistic groups, 'the pure people' versus 'the corrupt elite', and in response argues that politics should be an expression of the volonté générale (general will) of the people". Another school of thought focuses on leadership itself rather than on ideology when studying populism. The strategy approach examines the standpoint of a leader and their personality as they form a connection with the people (Weyland 2001). A third scholarly approach to populism frames it as a discourse of the underdog or 'the people' (De Cleen and Stavrakakis 2017; Moffitt 2016; Laclau 2005). The fourth and most recent approach looks at the language that populist leaders adopt, as they set themselves apart from 'the elite' and attempt to forge a close connection with 'the people.' Analysts describe this as "a political style that features an appeal to 'the people' versus 'the elite'; 'bad manners' and the performance of crisis, breakdown or threat" (Moffitt 2016, p. 45). In this approach, the focus is on the appearance, speech, choice of language, and demeanour of the party or its leader.

While these categories of populism are distinct in their framing, in practice political figures tend to employ a blend of these approaches. Despite the difference in options and the lack of a concrete definition, the polarising nature of populism is broadly agreed upon in that it casts society in binaries of 'in group' and 'out group.' This classification of 'in group' and 'out group' is based on socio-economic, religious, and political divides (De Cleen and Stavrakakis 2017; Rooduijn 2015).

Many centrist and establishment politicians have been as adept as their populist rivals in the use of cyberspace (Postill 2018, p. 756). However, among politicians, the populists have been particularly interested in a close connection to the people (Taggart 2002, p. 67). They are the stars in political cyberspace and outshine their centrist opponents (Hendrickson and Galston 2017). Populist communication manifests itself by emphasising 
the sovereignty to the morally pure people, advocating for the people, attacking corrupt and evil elites, ostracising dangerous others such as minorities or foreign powers, and invoking the heartland (Engesser et al. 2017, p. 1111). In this framing, the populists construct themselves as the true representatives, advocates, and mouthpieces of the people. Thus, they require "direct, unmediated access to the people's grievances" (Kriesi 2014, p. 363). Cyberspace has enabled this populist desire very effectively. While all media establish a connection to the people, cyberspace and social media provide the populists with a much more direct linkage (Engesser et al. 2017, p. 1113).

The relationship between cyberspace and populism has been increasingly studied by scholars (see, for example, Gerbaudo 2018; Krämer 2017; Postill 2018). Scholars have noted that the new wave of populism has emerged a result of the convergence of global trends: worsening economic prospects; real or perceived anxiety of losing cultural, social, or political status; and swift technological changes in relation to cyberspace opening a gulf between ordinary citizens and the elites (Gerbaudo 2018). Gerbaudo (2018) labelled the fusion of populist and cyber activism as cyber populism. With the popularity and pervasiveness of cyberspace, populist discourses have flourished in cyberspace, mainly on social platforms (Tong and Zuo 2020, p. 364).

While the popularisation of digital platforms has facilitated the process of political communication, social networks have become one of the preferred communicative tools for populists (Guerrero-Solé et al. 2020, p. 1). They have been actively using not only the mainstream media but also omnipresent cyberspace to promulgate their ideas among supporters (Bracciale and Martella 2017; Engesser et al. 2017; Kreis 2017; Zulianello et al. 2018). They have incorporated social media networks into their propaganda strategies. More research is needed to understand the role played by social media in spreading populism (Vreese et al. 2018). However, the use of social media is thought to give more freedom to populists to attack elites (Klinger and Svensson 2015), and therefore has facilitated anti-elite populism (Suiter et al. 2018). Also, social media communication tends to be more personal and emotional (Klinger and Svensson 2015; Enli 2017).

Cyberspace helps to mainstream populist values into political debates about controversial issues and, by being included in political debates, deviant political values are pushed toward the centre (Tong and Zuo 2020, p. 373). Populist discourses thrive more easily in the cyberspace since the gate-keeping role of the news media is absent (Engesser et al. 2017, p. 1123; Tong and Zuo 2020, p. 373). Cyberspace provides a direct linkage to the people and allows the populists to circumvent the journalistic gatekeepers that generally adhere to professional norms and news values, providing the populists with the freedom to uncontestedly propagate their ideology and messages (Engesser et al. 2017, p. 1110). Populists claim to own the truth and real information; thus, journalists become useless (Campos 2021, p. 5). Since the populist messages do not have to follow the news values, they are frequently more personal and sensationalistic in nature (Engesser et al. 2017, p. 1123).

Populist narratives translate well into short tweets and posts that reinforce the tendencies of some people and spark feelings of outrage in others (Berezin 2016; Hendrickson and Galston 2017). Since social media users do not usually adhere to any ethical media conduct, they can easily spread misinformation that can contribute to racism, xenophobia, and sexism (Campos 2021, p. 5).

Given the growing lack of trust in the mass media and professional journalists, most people receive news from family and friends, and they are more likely share this type of news than more traditional media articles (Campos 2021, p. 6). Coupled with this, populism had concurred with the evolution of social media algorithms, leading to more polarisation (Campos 2021, p. 7). Populists use social media not only as an effort to mobilise against and politicise a particular issue, but also as an infrastructure that allows for the inadvertent spread of misinformation as well as for the deliberate spread of disinformation about the issue at stake (Conrad 2021, pp. 301-2). It has been demonstrated that false news stories travel much faster online than true ones (Vosoughi et al. 2018). 
Populists in Indonesia provide significant empirical evidence that support the findings of the above-mentioned scholarly literature on populism, cyberspace, and social media.

\section{The Evolving Traditions of Populism in Indonesia}

Half a century after gaining independence, Indonesia entered into an abrupt democratic transition following four decades of military-backed authoritarianism. On the 21 May 1998, President Suharto resigned after more than 30 years in power. Thrust into a transitional role, former vice-president B.J. Habibie succeeded in an ambitious program of democratic reforms which continued under President Abdurrahman Wahid, a progressive cleric and civil society activist who was elected in October of the following year. Defying expectations, the military was substantially side-lined, and democracy was consolidated (Barton 2002).

Indonesia's first two presidents, the extroverted and eloquent Sukarno and the introverted and enigmatic Suharto, both deployed elements of populism in claiming extraordinary executive powers. Since then, populism in various guises has remained a permanent fixture in the politics of Indonesia. From presidents to leaders of vigilante Islamist groups, populism has figured prominently in the mobilisation of mass-support (Mietzner 2020; Hara 2017).

A decade after the Asian Financial Crisis of 1997 that plunged Indonesia into a deep recession, and led directly to Suharto's resignation, Indonesia embarked on the path of a steady economic group averaging $5 \%$ per annum, lifting the world's fourth largest nation into the first rank of emerging economies, with a Gross Domestic Product (GDP) of more than a trillion dollars. At the same time, however, Indonesia has become the sixth most unequal place on the planet when it comes to income distribution. In the PostSuharto era, the oligarchs have benefitted disproportionately as Indonesia has continued to see rapid growth in GDP coexisting with stubbornly high levels of unemployment and underemployment (Tadjoeddin 2019; Hara 2017). By 2014, the leading political parties of the governing coalition, PDIP (Partai Demokrasi Indonesia Perjuangan-the Indonesian Democratic Party of Struggle) and Gerindra (Gerakan Indonesia Raya-the Great Indonesia Movement Party) were judged to be failing in fulfilling the dreams of 'the people' or the 'common folk' (Mietzner 2020; Yilmaz 2020; Fossati and Mietzner 2019; Hara 2017).

Both Gerindra and PDIP have responded to the frustration with the lack of economic progress felt by many by endorsing populist leaders who are better able to accommodate the changing mood of 'the people.' At the same time, sharpening perceptions of inequality combined with a changing global environment have provided new opportunities for Islamist actors to contest the political arena (Hadiz 2016).

As Mietzner (2020, p. 421) notes with respect to Indonesia, "three competing forms of populism have contested power since the early 2010 s ... Chauvinist and Islamist populists have openly advocated against the existing democratic status quo, while more moderate, technocratic populists have offered themselves as a middle-way alternative". The roots of Indonesia's transition to an independent nation-state mean that populism was embedded early on as a part of the political landscape. Post-independence politics in Indonesia were dominated by nationalism; this was artfully invoked by Sukarno during the period of 'Guided Democracy'. This framed opposition figures as dangerous 'traitors' threatening national stability (Leslie 1957).

Spiralling social and economic instability in the late 1950s and early 1960s ultimately led to Sukarno's denouement. A year of hyperinflation and a mysterious event framed as a coup in October 1965 led to a massive, bloody purge of members and alleged supporters of the Communist Party of Indonesia (PKI) and to regime change. Another authoritarian president came into power when the hitherto low-profile General Suharto replaced the extroverted style and soaring populist rhetoric of President Sukarno with a softly spoken, enigmatic command of power that channelled Javanese conceptions of kingship. This positioned Suharto as a stately outsider who answered the call to duty to become a national saviour. This led to a period of political and economic stability that saw significant growth 
in the country's Gross Domestic Product (GDP), continuing up until the Asian Financial Crisis of 1997. However, income disparities between rural Indonesia and major cities such as Jakarta, Bandung, and Surabaya remained high (Muhtadi and Muslim 2020; Sub 2016).

After the fall of Suharto, previously marginalised Islamist actors seized hold of the rhetoric of social justice and merged it with the language of Islamist politics in a populist fashion to create a divide between the 'pious' and the 'elite' (Hadiz 2016; Fukuoka 2013; Zarkasyi 2008). Despite this, Islamist parties have not been able to win a significant share of the vote in Indonesia (Barton 2010a). Consequently, in order to obtain political leverage, they have aligned themselves with opposition groups or right-leaning parties. Over the past decade, one such party has been Gerindra (Partai Gerakan Indonesia Raya-Great Indonesia Movement Party), created and led by Prabowo Subianto (Mietzner 2015). A senior member of the political elite, Prabowo is a former military officer and the son-in-law of Sukarno. Over its brief history, Gerindra has dallied with Islamist alliances whilst asserting itself as being a champion of the 'poor' by appealing to rural and working-class backgrounds. Prabowo presents himself as a reformist strongman promising to upend the system of elite corruption and moral decay. Channelling his military service, the former general and one time commander of the notorious Kopassus special forces has promised strong, competent, 'efficient' leadership to address the issues of 'the people.' Mounting the platform of Gerindra, Prabowo has deployed a classic 'third world' populist style in evoking religious divides and calling for the end of corruption, casting himself as a strongman who is able to manage the country he loves. A soft emphasis on revolution has allowed Prabowo to use authoritarian overtones reinforced by a remarkable military career to convey a compelling 'strongman' image (Mietzner 2015).

Another form of populism that has emerged in post-Suharto Indonesia is a populismlite or technocratic populism, which eschews the imagery of a military strongman in favour of bold technocratic entrepreneurship arising from the real world of business outside of the Jakarta political elite. Joko Widodo (Jokowi), the head of state for the second term, and the Indonesian Democratic Party of Struggle (PDIP) are proponents of this less overt form of populism (Mietzner 2015). Compared to the familiar variations of reformist right-wing populism, this variant represents a more liminal form. Jokowi is the face of this more subtle form of populism, where a blend of personalistic style and practical solutions is the focus. As a Central Java businessman from an impoverished background, Jokowi connects with 'the people', and his story of a self-made man rising out of a childhood in a modest riverside hut to become the two-term Mayor of Solo, then Governor of Jakarta, and finally President, carries with it the hope of triumphing over the 'political elites' who have failed to deliver (Mietzner 2015). With promises of reform pitched in concrete terms, Jokowi has based his political appeal on technocratic populism that offers people improved public service delivery (Yilmaz 2020). Beneath the beguiling everyman guise of naïve outsider, however, there is evidence of considerable political savvy. To counter Prabowo's opportunistic embrace of a campaign of mass protests against Ahok, his long-term friend and political partner, and his successor as Governor of Jakarta, spearheaded by FPI (Front Pembela Islam-Islamic Defender's Front) and MUI (Majelis Ulama Indonesia-Indonesia Council of Ulama), Jokowi appointed MUI Chairman Ma'ruf Amin as his vice-presidential running mate (Barton et al. 2021b; Chew 2019). Furthermore, in the face of mounting criticism fuelled by the economic impact of the COVID-19 pandemic, Jokowi has shown signs of authoritarianism in dealing with political opposition figures (Barton et al. 2021b; Arifianto 2019; Bland 2019).

With the ending of Suharto's New Order regime, Indonesia fared well on many fronts compared to many other Muslim majority countries (Barton et al. 2013); however, even with the consolidation of democracy and a return to economic growth, many felt left behind (Barton et al. 2021b; Nuryanti 2021; Yilmaz 2020). In the eyes of many, Indonesia has faced a deepening of "(a) pre-existing religio-racial, regional or class divisions, (b) the politicisation of socioeconomic inequalities within the framework of those divisions, (c) the availability of minorities as mobilising targets for populist campaigns, and (d) the willingness of 
established parties to support populists in order to retain political significance" (Mietzner 2020, p. 421). These factors combined have contributed to the development of a political environment in which traditional political parties have increasingly formed alliances with populist actors (Mietzner 2020).

\section{Religious Populism}

After gaining independence from the Dutch, Sunni Islamic parties have existed as an integral part of Indonesian politics which Jati (2013) categorises as "Nahdlatul Ulama (NU-the Awakening of Ulama), the modernist Islamic political party, Masjumi (Council of Muslim Organizations) and the militant Islamist movements, Darul Islam (DI- Home of Islam) and Tentara Islam Indonesia (TII-Indonesian Islamic Army)" (Barton 2010b).

Proto-Islamist actors and more radical movements calling for the implementation of sharia and for Indonesia to be constituted as an Islamic state were seen to be dangerously divisive. This was made much worse by insurgent movements such as the Darul Islam (DI) or Indonesian Islamic State (NII) movements in West Java and South Sulawesi that, post-independence, broke ranks with the numerous nationalist militia that had fought the Dutch (Hadiz 2016, p. 120).

Tomsa (2019) points out that while Islamist parties mostly started with the call for sharia-based political and social reforms in the 1950s, over the years more radical expressions of Islamist politics were replaced by a more acceptable form of social conservatism: "Both the United Development Party (Partai Persatuan Pembangunan/PPP) and the Prosperous Justice Party (Partai Keadilan Sejahtera/PKS) abandoned their original goals of turning Indonesia into an Islamic state based on sharia law. Like other radical parties in similar political contexts, they moderated in response to institutional incentives and immersion in parliamentary and cabinet politics" (Tomsa 2019). In essence, while conservative Islamic parties based on right-wing ideals have been active coalition partners in various governments, they have done so by adopting a much less radical approach.

In Indonesia, PKS (Partai Keadilan Sejahtera-the Prosperous Justice Party) is a leading example of a political party has partly merged welfarism with its politics while it largely caters to the conservative, urban, educated middle-class during its evolution from the radical Islamist far-right to social conservatism (De la Torre 2019). This dawah-based party is responsible for bringing the ideas of the Egyptian Muslim Brotherhood to Indonesia. It has focused on propagating the idea of Islamist social justice and calling for an end of corruption as the central elements of its populist appeal (Temby 2020; Permata 2008; Machmudi 2008). On the other hand, PPP (Partai Pembangunan Persatuan-the United Development Party) represents an amalgamation of several Islamic parties that were forced to combined during the Suharto era (Barton 2006). Ultimately, as moderate expressions of Islam have dominated the politics of Indonesia, Islamist parties such as PPP and PKS have struggled to position themselves as populist parties (Epley and Jung 2016).

More moderate Islamic parties such as the NU-based PKB (Partai Kebangkitan Bangsathe National Awakening Party) have found broader appeal by blending Islam and nationalism. PKB reached its zenith when NU leader Abdurrahman Wahid, who founded PKB as a moderate non-Islamist alternative to PPP, was elected president in October 1999 (Barton 2002). A review of the 2009 manifesto of the party shows that, while the party has taken a more centrist approach in politics, it continues to frame its ideological position in Islamic terms. It says that it aims to solve social issues and problems in society in line with Islamic moral derivatives. Its language, conception of problems and solutions, and political rhetoric are all rooted in an Islamic connection of these ideas (PKB 2014). Wahid's time in office positioned PKB in more progressive terms, and during his short-lived government he boldly promoted ideas of interfaith dialogue and normalisation of relations with non-Muslim countries, including even Israel (Barton 2002). NU itself has been a politically active group that has been part of the country's early politics and, with around 40 million affiliates, is Indonesia's largest Islamic organization. The backbone of NU is its system of pesantren (hybrid Islamic and secular residential schools) and other welfare projects 
(Feillard 2013). Post 9/11, with the surge of Islamist terrorism in Indonesia, NU leaders have sought to play a more pivotal role in acting as a buffer between extremist Islam and society by promoting Islam Nusantara, a moderate Indonesian expression of Islam (Fealy and Bush 2014; Feillard 2013). For instance, following the protests against the Chinese governor of Jakarta, Basuki Tjahaja Purnama, widely known as 'Ahok', and NU partnered with young Catholic activists for a citizenship-based activism that opposes the idea of a religious-based right-wing activism (Nilan and Wibowanto 2021).

While a number of Islamic political parties and groups have focused on maintaining a balanced view, this case is not true for all groups. The Indonesian Muslim Intellectual Association (Ikatan Cendekiawan Muslim Indonesia/ICMI) was created by Suharto as a tame conservative special interest group to manage Islamist activism (Nuryanti 2021). The group tapped into the rhetoric of Islamist welfarism and social justice, giving voice to the frustrations of the rural and urban poor who have felt left-out by the mainstream policies for decades. Nevertheless, it was originally disassociated with the grassroots and was sustained on the patronage of the state as a pressure group. ICMI "characterises Muslim intellectuals as people or a group of Muslims who pay attention to their environment, continuously improve their quality of belief and devotion, improve their thinking ability, deepen science and technology and try to understand and put science, technology, and religious life into practice in their society in the interest of human prosperity" while it has fanned a passive aggression against the ethnically Chinese Catholic community of Indonesia that has been well positioned in the government agencies as well as economic sectors of the country (Niam 2010, p. 291; Federspiel 1991).

In addition to ICMI, other right-wing groups with an Islamist orientation have constantly used a populist appeal of 'otherizing' the Chinese community in Indonesia as a threat to the ummah (De la Torre 2019, p. 174). Economic liberalisation has only strengthened this stance as the community has benefited greatly from the economic model and have become part of 'the elite', while right-wing Islamicists have used this position to make them scapegoats for the problems of the working-class Muslims of Indonesia who have felt left behind (De la Torre 2019, p. 184). Despite being created by Suharto as a vehicle for managing and containing Islamist activism, by 1997 various prominent figures from ICMI called for Suharto to step aside and make way for democracy as they "militantly campaigned by calling for Soeharto's resignation from the presidency. At the same time they increasingly promoted democracy as representing the only way out from political and economic crisis that struck Asian countries in 1997" (Jati 2013).

MUI (the Indonesia Ulama Council), another religious special interest group produced by Suharto's New Order regime, was established as a non-political religious group intended to act a moderating power broker between the state and various radical groups (Schäfer 2019). While it remains outside the ambit of electoral politics in the post-Suharto era, MUI has become an active populist political force generally inclined to champion conservative Islamist interests. As noted above, MUI took a central role in supporting protesters during the anti-Ahok rallies of late 2016 and early 2017. It was MUI that took the lead in framing Ahok as a 'blasphemer', contributing to the acceleration of the events (Yilmaz and Barton 2021b). MUI derives its main source of power from its self-appointed authority to issue national fatwa: "It is not merely the anti-pluralist content of the fatwas themselves that is democratically problematic, but rather the larger, more comprehensive claim of the council to be an expert authority, whose views and verdicts cannot be challenged by political authorities" (Schäfer 2019, p. 240). Using the general tide of populist rise and a growing mainstreaming of religious populism, and with MUI's "capacity as a semi-official advising institution, the council has undermined Indonesia's young and fragile parliament through its epistocratic claims and by damaging the public standing of established civil society organizations, whose competition had ensured a low degree of centralization of religious interpretative authority for many decades" (Schäfer 2019, pp. 254-55).

In Indonesia, as in many other Muslim-majority countries around the world, populist Islamist groups have at times resorted to the extremes of a jihadist approach. While jihadi 
groups have operated at a remove from mainstream politics, they have enjoyed dalliances with Islamist parties and politicians and have continued to make their presence felt (Jati 2013). Over time, prominent groups have included Laskar Pembela Islam (the militia wing of FPI), Laskar Jihad, Laskar Mujahidin Indonesia, and, most notoriously of all, Jemaah Islamiyah (JI). Support for these groups has been strongest in communities where there is a feeling of resentment and inequality; thus, the victimhood narrative and insecurities, both economic and social, have given these groups a safe haven in vulnerable communities (Barton 2005, 2010a). While their jihadism took the form of an armed struggle at various points in Indonesian history, such as the independence struggle and the Afghan jihad, today they mostly carry out dakwah missionary activities, keeping the spirit of jihad alive in an acceptable fashion (Jati 2013).

Another version of far-right political parties has been parties that seek less direct involvement in politics and are highly involved at the grassroots level. One of the most prominent groups, until its recent ban, was FPI (Yilmaz and Barton 2021a; Yilmaz and Barton 2021b), formed by Muhammad Rizieq Shihab in 1998 after the fall of Suharto. Shihab and FPI boldly espoused right-wing Islamism as their ideology and over the years they had taken on vigilante activism to "save" Islam from "vice" through their moral policing activities (Amal 2020; Fossati and Mietzner 2019; Mietzner 2018). The group has opted for forceful Salafist ideology implementation, seeking its roots in Saudi Islamist theology (Barton 2021). Similar to other Islamist civilisationists (Yilmaz et al. 2021a, 2021b; Shakil and Yilmaz 2021), this radical activist religious populism divided 'the pious' ummah and demonised all who did not adhere to its strict codes; this ideology was propagated through its dakwah centres and social welfare activities along with its notorious militia (Barton 2021; Barton et al. 2021a, 2021b, 2021c; Yilmaz and Barton 2021a). Exploiting a sense of being 'left behind' by the state and its policies, FPI provided its followers with a victimhood identity and agency to 'get back' and 'reform' society with its vigilantism (Barton 2021; Barton et al. 2021b): "The FPI demonstrates the manner in which smaller, liminal, political actors can instrumentalise religion and leverage religious rhetoric to reshape political discourse, and in doing so, drive demand for religious populism" (Barton et al. 2021b).

FPI's firebrand leader, Rizieq Shihab, now serving time behind bars for flouting COVID-19 pandemic bans by organising large public gatherings, was a key element in mobilising opposition to Jokowi. The return of FPI's leader to Indonesia after a self-imposed exile led to a ban on the group, yet behind bars Rizieq continues to earn followers by portraying himself as the victim of the corrupt state as he refused to answer questions and instead dramatically recited Quranic verses during his court appearance, using populist symbolism and rhetoric effectively (Yilmaz and Morieson 2021). FPI was, for all its bluster, a rather peripheral actor, but its grassroots welfarism, anti-state stance, and call for revival of Salafist morality have given it a prominent voice in the surging right-wing momentum in Indonesia. Moreover, whilst FPI remains banned, its ideology continues to live and replicate in its former students and militia (Barton et al. 2021b; Yilmaz and Barton 2021b).

The failure of the ultra-right to significantly impact the 2019 election results despite the mass anti-Ahok rallies of late 2016 exposes the lack of deep, broad support for far-right Islamist politics (Hara 2019).

\section{Chauvinistic Populism}

A second very distinct form of populism is what can be referred to as chauvinistic populism. Chauvinistic populism emphasises the superiority of 'the people' over 'the others.' Unlike its technocratic counterpart, this variant of populism is not particularly subtle and uses sentiment about faith and nationalism mixed with the call of revivalism to stop 'foreign powers' and the 'enemies within' from taking away the rights and prosperity of 'the people' (Mietzner 2020). Prabowo Subianto is a notable exponent of chauvinistic populism in Indonesia. Whilst himself a member of the elite as a powerful general during the Suharto regime and the beneficiary of an expansive business network, Prabowo successfully reinvented himself as a politician, exploiting his falling-out with the Suharto 
family to distance himself from 'the elite', all the while remaining very much a part of the Indonesian oligarchy (Mietzner 2020).

Prabowo's core rhetorical theme is that the 'corrupt' elite have been looting the poor and rightful people of Indonesia. In this narrative, he has added a tone of jingoism that also calls out 'foreign powers' for exploiting the riches of Indonesia. Extending this criticism to the political establishment, in a classic populist tone, Prabowo presents himself as representing an 'efficient' strongman who can 'clean up corruption' in Indonesian society (Aspinall 2015, p. 2; Mietzner 2020). His campaign speeches draw heavily on populist ideas to cast in a populist chauvinistic mode. For example:

"All you who want Indonesia to remain poor, all of you who steal the people's moneyI will not waver in the face of you! If you all say that the Indonesian nation can be bought, I say it cannot be bought! ... If you all want to commit fraud, brothers, I say 'go ahead,' and watch —watch! — what will be done by the Indonesian people! ... Beware all you foreign stooges! All you who can only slander, can only insult people, but have never defended the people, never gave thought to the people, never gave thought to the poor, who only at election time pretend to care for the people ... Do you think that the Indonesian nation is one that can be lied to continually? Brothers, our struggle is right! Our struggle is right! We struggle for justice, we struggle for an Indonesia which is respected, we struggle for an Indonesia which can stand on its own feet! ... we do not waver in the face of your trickery ... Beware all you who are used to stealing the Indonesian people's money-I don't need to name them one by one, but when the time comes, if necessary, I will name them, brothers ... beware all of you who have a vision of an Indonesia broken apart, of a poor Indonesia, we say: no! This time, NO! ... Indonesia wants to rise up, brothers ... the Indonesian people want justice, the Indonesian people want a leader who is clean, who doesn't pretend to be of the people, yet steals the people's money!" (Aspinall 2015, pp. 19-20).

Religious and ethnic divides are central to Prabowo's narrative. At times, he targeted Indonesia's economically prosperous community of Chinese elite businessmen as being allied with China (Mietzner 2020). This targeting of the Chinese community peaked during his 2019 campaign, when he led the anti-Ahok protests that allowed him to allude to idea of the Indonesian Chinese community as being the 'enemy' of not only the state but also the faith during the blasphemy fiasco (Barton 2021; Yilmaz and Barton 2021a; Yilmaz 2020). It is, however, interesting to note that Prabowo comes from a household where his immediate relatives consist of both Muslims and Christians. Prabowo's brother Hashim Djojohadikusumo, a Christian, is the main financier of his campaign. At the same time, Prabowo himself is not known to be an observant Muslim, nor does he pretend to be so (Mietzner 2020). Yet despite these differences, during the 2019 political elections, Prabowo effectively enlisted Islamic populism as a key element of his campaign. His alliance with the Islamist right was diverse and complex. On the one hand he aligned himself with far-right vigilante Habib Rizieq Shihab and his FPI for fiery street power during the anti-Ahok demonstrations; on the other hand, he forged ties with Amien Rais, a well-respected Islamic politician and leader of PAN (Partai Amanat Nasional-the National Mandate Party) (Hara et al. 2019; Hara 2017). Prabowo used the campaign for the 2017 election for Governor of Jakarta as an early mobilisation vehicle for his campaign for the 2019 presidential and parliamentary elections. In late 2016-early 2017 Jakarta campaign, he backed the high-profile Islamic intellectual Anies Baswedan as candidate for governor and the popular entrepreneur Sandiaga Uno-Sandi-as his running mate. The pair were successful in defeating the incumbent Ahok. Prabowo went on to select Sandi as his running mate for the 2019 election. The Prabowo-Sandi duo thus became part of a deeper wave of Islamisation that brought together various right-wing parties and actions in an Islamism populist fashion under the call of Ukhuwah Islamiyah (Islamic solidarity) and dakwah (religious appeals) (Hara et al. 2019; Hara 2017).

In his campaign speeches, Prabowo also freely employed rhetoric that was not only jingoist but also narcissistic. He presented himself as being the 'capable' leader that the 
nation needed to lead a war against all 'the enemies' of the people. His style, mannerisms, and rhetoric as the 'saviour' of the nation borrowed heavily from Sukarno. While Prabowo has, so far, been unable to win an electoral victory with his populist ideas, he has "comprehensively reshaped the Indonesian political landscape-mainly by enabling one stream of Indonesian populism (Islamism) and imposing some of his ideas on another (the technocrats' populism 'light')" (Mietzner 2020).

Using constitutionalism, Prabowo has "deployed political rhetoric that draws on ideas used by Suharto's New Order regime" while he draws his support from the oligarchs, non-Gerindra voters and parties, and a diverse network of patronage to various formal and informal organizations across the country (Satrio 2019; Aspinall 2015, pp. 19-20). Fossati and Mietzner (2019) drew on field research with voters to shed light onto the support received by Prabowo. They found that Prabowo was able to position himself not just as the voice of the poor but also as the spokesman for a more middle-class and elite segment that in Pepinsky's words is summed by Fossati and Mietzner (2019) as the following: "The success of order-first political strategies reflects elite and middle-class frustrations with unstable and ineffective governance, combined with a historically rooted belief that political stability and material progress require the elimination of disorderly elements."

Prabowo's effective framing of a national crisis threatening the security of the nation as a whole, and the Muslim ummah in particular, made him an effective chauvinistic populist who could bring together various insecurities and rifts in society under one umbrella. This might not have helped Prabowo secure a winning majority in the 2019 elections, yet it was nevertheless sufficiently effective in demonstrating a significant appetite for populism and Islamism in Indonesia.

\section{Technocratic Populism}

Not all populist leaders and parties deploy a fire-brand persona or display flare for dramatic rhetoric. A more mellow or "middle-way" approach is also taken by some leaders that can be described as "lite-populism" or technocratic populism (Mietzner 2020, p. 241). In Indonesia, as mentioned above, technocratic populism has surfaced under the leadership of President Joko Widodo, widely known as Jokowi. His approach has not been that of appealing to religious conservatism or anti-elitism. It is rather founded on a promise of practical solutions offered to the people to address their day-to-day issues. Buštíkovà and Guasti (2018) describe "Technocratic populism as using the appeal of technical expertise to connect directly with the people, promising to run the state as a firm, while at the same time delegitimising political opponents and demobilising the electorate by instilling civic apathy." Thus, while remaining true to the anti-elite stance there is an air of confidence that Jokowi has been able to emanate that shows his expertise and authenticity for solving the issues of the common people.

Given his background outside of national politics, and coming from Solo, deep in the heartland of Central Java, Jokowi was naturally positioned as being 'close' to the ordinary people. His more recent governorship of Jakarta focused on management issues and contributed to the credibility of his technocratic 'lite-populism' in his campaign for the 2014 elections. These factors have combined to keep Jokowi away from the more vulgar expressions of populism that rely on an excessive focus on nativist nationalist stance or reformist economic rhetoric. Jokowi's outsider stance was also an important novel element in Indonesian politics where all previous political leaders have been from oligarchical families and the military elite in Jakarta. Amongst a voting base disillusioned with the establishment status quo, the new face and fresh technocratic populist appeal of Jokowi quickly found broad support (Yilmaz 2020). All these characterisations have allowed Jokowi to embody the volonté générale of 'the people' as opposed to the ultra-rich and military elite (Mietzner 2020, pp. 428-49).

The 2014 elections happened at a time when the country had become increasingly dissatisfied with status-quo politics after Susilo Bambang Yudhoyono's decade in office. Dissatisfaction with the mainstream allowed for new expressions of populism to find room 
and flourish. In the 2014 election campaign Prabowo was the traditional populist who waged a war on corruption and the "rotten" in the system, while his contender, Jokowi, took a softer approach by advocating for a "pro-poor governance" (Mietzner 2015). The promise of non-accommodation for the self-interested elites, however, was difficult to maintain post-election victory for the president.

While Jokowi surfaced as a technocratic populist, his second term in office is now showing clear signs of a change. The populist promises from the 2014 campaign were not entirely fulfilled once he come into direct confrontation with the political elite comprised of a military and civil oligarchy (Mietzner 2020; Yilmaz 2020; Bland 2020; De la Torre 2019; Bland 2019; Power 2018). While his rise to power has kept traditional authoritarian and oligarchic populists at bay, his sway in politics has suffered due to the constant accommodations Jokowi has made to the elite (De la Torre 2019, p. 376). In a bid to ensure some fulfilment of his promises, the president has pushed for economic growth highly reliant on Chinese debt; this has helped him realise his technocratic promises, but the country's external debt has soared beyond 8\% (Yilmaz 2020).

During his term in office, Jokowi has come to use "legal instruments in this manner" and is "far more open and systematic" when it comes to facilitating the government: "by turning the institutions of security and law enforcement against democratic opposition, the Jokowi administration has overseen a blurring of the lines between the interests of the state and those of the government" (Power 2018). Other than mainstream opposition, the government has also used security forces to curb grassroots movements, as in the following two examples. Firstly, the grassroots opposition movement \#2019GantiPresiden surfaced on the internet calling for 'a change of President in 2019'; a number of those who shared the hashtag were threatened with treason charges and stalls selling the themed merchandise in the markets were vandalised by the police force (Power 2018). Secondly, a similar degree of intolerance has been displayed in 2021 towards FPI or the Islamist Islamic Defenders Front-Front Pembela Islam (Barton 2021). The group has been banned after an encounter that led to the death of six of its members on charges of terrorism and saw its leader jailed (Barton et al. 2021b; Yilmaz and Barton 2021a). The excesses of this vigilante Islamist group had previously been tolerated, but this changed abruptly when action was taken against Rizieq Shihab, who had recently returned from a period of self-imposed exile in Saudi Arabia to run a campaign of a 'moral revolution' as the government suffered from rising public criticism, due in part to its perceived mishandling of the COVID-19 pandemic (Barton et al. 2021b; Yilmaz and Barton 2021a).

While the Attorney General's office and security forces are increasingly being used as "political weapon" by the government to "to control opposition politicians", there has also been an increase in reintegrating the military with matters of the state (Power 2018). During his second term, Jokowi has established closer ties with the military. In Indonesia, where military-backed authoritarianism has marred the growth of open society, this rapprochement with the military is alarming. The government has repeatedly called upon military and police officers to promote the government's achievements at the grassroots, with Jokowi saying: "In relation to government programs, the work that we have carried out-I ask all officers to go and promote this to the community. Pass on these [accomplishments] whenever the moment is right to do so" (Power 2018).

Another substantial change, while adjusting to shifting political realities, has been the reframing of Jokowi as a good Muslim leader rather than as a champion of religious minorities (Mietzner 2020; Yilmaz 2020; Bland 2019). Since the anti-Ahok street protests of late 2016, there has been increased pressure for the government to take a stance that accommodates aspects of Islamism (Bland 2020). In the 2014 elections, Jokowi won 90\% of the non-Muslim vote and significant support from the Muslims came from moderate groups; however, seeing the change in attitude over sentiments related to Islam, Jokowi is now seen to be at risk of being co-opted by the Islamist far-right (Mietzner 2020). Prabowo's use of the far-right was countered by Jokowi's embracing pf the Islamic right when he chose as his running mate Ma'ruf Amin, the Chairman of MUI. Thus, the 2019 election showed 
signs that Jokowi's 'lite-populism' had evolved into a hybrid populism that borrowed some of the elements of chauvinist and Islamist populism from Prabowo: "he [Jokowi] adopted some chauvinist elements-such as tough talk on defending Indonesia's territory against any ambitions by foreign powers; echoing the military's rhetoric on a continued communist threat; as well as a shoot-on-sight policy for drug dealers. At the same time, he portrayed himself as more Islamic, acceding to a new wave of religious conservatism in public life" (Mietzner 2020).

This co-optation extends beyond partnering with the right-wing and making compromises with the elite. To ensure his political survival, Jokowi, on 23 October 2019, appointed his political opponent Prabowo as Minister of Defence, in what was seen as a classically Javanese power-play. "After securing the highest office, he [Jokowi] has increasingly pursued compromise and co-optation, most evidently in his decision to appoint Prabowo [ ... ] Jokowi dismissed criticism of this move by arguing that Indonesian democracy is not based on oppositional politics, a foundation stone of liberal democracies, but 'mutual cooperation'" (Bland 2019).

In essence, the populism of Jokowi has evolved from being that of a 'man of the people' to a growing blend of soft-authoritarianism and use of Islamic imagery in an attempt to co-opt and adjust to changing political realities. This transition has also been supported by the digression that the constitution of Indonesia allows to the government in power due to it foundational roots in the 'New Order' which Jokowi has instrumentalised (Satrio 2019). As De la Torre (2019) points out, over time Jokowi's "own version of softer, technocratic populism was strongly diminished by his need for continued elite accommodation", which has left him outside any specific class of populism, making him a realist who adopts various streams of populism in ad hoc bases to meet the political challenges at hand (Bland 2020).

\section{Populists' Use of Cyberspace in Indonesia}

Indonesia's population has been amongst the most enthusiastic 'uptakers' of the internet, especially of social media, as most of them use the internet as an information source, including for religion (Solahudin and Fakhruroji 2020, p. 1). In the beginning of the 2010s, Indonesia had become the third largest nation on Facebook with 43 million users and fifth on Twitter with 29.4 million users. The Indonesian blogosphere has grown rapidly from only 15,000 bloggers in 2007 to 5 million as of 2011 (Lim 2015, p. 130).

A report has found that Southeast Asians generally trust social media platforms more than people in Western societies, reflecting a lack of trust in local mainstream media and official sources of information (Tapsell 2020). Key to understanding this heavy use of the cyberspace in Indonesia is the loss of trust in traditional sources (Tapsell 2020, p. 6). The legacy of authoritarianism and state-sponsored propaganda has had a lasting impact (Tapsell 2018). Citizens grew up on a diet of pro-government official propaganda and then turned to unofficial sources of information (Tapsell 2020, p. 8). Passing on information, rumours, and gossip became part of being an Indonesian citizen who passes on the extra information (Tapsell 2020, p. 9).

The utilisation of cyberspace in Indonesian politics has been studied in previous research (e.g., Lim 2013, 2017; Miichi 2014; Aspinall 2015; Tapsell 2017). The importance of cyberspace and social media in Indonesian politics came into the light for the first time in 2009. In this year, there were two important events: a massive rally against corruption, and the presidential election. The mass rally was organised by Facebook users to support the Corruption Eradication Commission against the Indonesian National Police, who were perceived as corrupt (Nadzir and Rastati 2020, p. 178). The second important event in 2009 was the presidential election. The success story of Obama in the USA inspired Indonesian politicians to gain similar success in transforming social media support into votes (Nadzir and Rastati 2020, p. 178). Joko Widodo (Jokowi), Anies Baswedan, and Ridwan Kamil demonstrate the new wave of politicians that utilise cyberspace as an integral part of their electoral campaigns (Nadzir and Rastati 2020, p. 179). 
Since 2014, however, Indonesia has become more politically polarised. Three major elections have left the country more divided than it has been in decades: the 2014 presidential election, the 2017 gubernatorial election in Jakarta, and the 2019 presidential election. As Johansson (2016) has shown, social media in Indonesia has become the dominant domain of political communication based on identity politics as an alternative to traditional media controlled by conglomerates (Genta and Wihartano 2018, p. 53). The spread of political discourse based on religious identity has become more massive through cyberspace, especially through social media such as Facebook, Twitter, YouTube, and mass media (Genta and Wihartano 2018, p. 53).

One of the most profound examples of religious populism and its intertwining with cyberspace was the Ahok incident. Competition between President Joko Widodo (Jokowi) and his former opponent, Prabowo Subianto, ignited a previously latent political cleavage between Islamists and pluralists (Warburton 2020, p. 25). In 2014, Prabowo and his allies spread the message that Jokowi was not a pious Muslim and that his politics were too secular to govern a Muslim-majority nation. Simultaneously, a more sinister smear campaign was run in the shadows via anonymous social media accounts (Warburton 2020, p. 27). Jakarta's popular governor, Basuki Tjahaja Purnama (known as Ahok), was the target of a more explicitly sectarian campaign in the 2017 Jakarta election. As a Christian, ethnically Chinese Indonesian and Jokowi ally, Ahok attracted extremist opposition from Islamist groups that argued a non-Muslim had no right to hold high political office in a Muslim-majority country. There were two election campaigns: the official campaign where candidates talked of policies (such as education and entrepreneurship) and the more emotive "unofficial campaign" online where voters were asked not to vote for Ahok because he had allegedly insulted the Quran, or more covertly, because he had Chinese heritage (Tapsell 2020, p. 11). A heavily-edited Ahok campaign video surfaced in late 2016 and went viral, contributing to the rapid emergences of the mass right-wing movement: Action to Defend Islam-Aksi Bela Islam-(Nuryanti 2021; Barton et al. 2021b; Amal 2020; Mietzner 2018). Anti-Ahok protests accused the Governor of Jakarta of blasphemy. Thousands participated because the Muslim majority felt it was insulted by the critical comments made by the Chinese Christian governor. This made the Muslims "the people" while the "blasphemous" content of Ahok was cast as the enemy of the ummah (Adiwilaga et al. 2019, p. 169).

Ahok's opponent, a Prabowo ally named Anies Baswedan, joined forces with the hardline Islamist groups opposed to Ahok, and these groups spread a sectarian message through prayer groups, mosques, and especially online networks (Warburton 2020, p. 28).

As a result, Ahok was ousted and ultimately jailed for blasphemy. Social media discourse, and the ability of campaigners to target Muslim voters on their pages, was not the sole cause of this election campaign and its result, but it undoubtedly played a role. This movement created an opportunistic space for Islamism in Indonesian politics, where major religious parties had long assumed a more centrist stance.

The Jakarta elections signified the role of cyberspace and became an important moment in the proliferation of intentional engineering of political environments in cyberspace (Genta and Wihartano 2018, p. 48). It also exemplified how online political contention can be materialised into physical mass movement on the streets (Genta and Wihartano 2018, p. 51). Since then, disinformation has become a politically significant mode of information (Genta and Wihartano 2018, p. 52).

Since the event, the use of cyberspace to disseminate populist political expression has become more prominent (Genta and Wihartano 2018, p. 54). Both sides, Jokowi supporters and those opposed to Jokowi, do the same by carrying out their discourses along with religious issues. However, what has been significant is the presence of public figures. The Ahok blasphemy case triggered the rise of Islamic populist figures such as Habib Rizieq and Anies Baswedan. Nonfactualist and sentimentalised narratives have been increasingly proliferated, especially in cyberspace, by various actors ranging from voluntary participants in discourses of war, to organised factories of fake news and hate. 
Moreover, these narratives that have accumulated in cyberspace are expressed by other freeriding figures, in the hybrid form of particular discourses. (Genta and Wihartano 2018, p. 56).

Right-wing parties and actions, including the opposition parties, used the Ahok incident's momentum in a campaign for the 2019 election that saw a surge in right-wing Islamist elements. While the elections did not see the front runners of the Action to Defend Islam ultimately victorious, it did force Jokowi to assume a more 'Islamic' outlook and stance to appeal to the recent rise in religiosity (Nuryanti 2021; Yilmaz and Barton 2021a; Barton et al. 2021b; Yilmaz 2020). The events surrounding the Ahok video clearly demonstrate the power of social media in the context of the propagation of Islamist populism, given that the video was heavily edited and misconstrued Ahok's statements to evoke emotions of ummah stemming from their sensitivities towards religion (Nuryanti 2021; Amal 2020; Mietzner 2018).

While Ahok was certainly a victim of social media driven populism, others have also come into the loop of blasphemy while making mistakes on social media during their discussions on Islam. Evie Eendi, a religious scholar, was accused of blasphemy by MUI after a controversial video of him surfaced (Solahudin and Fakhruroji 2020). MUI has repeatedly targeted individuals it deems a 'threat' to Islam on social media platforms to maintain its hegemony of religious populism (Solahudin and Fakhruroji 2020). The stance taken by MUI showed its inability to maintain a moderating presence and has threatened its hegemonic control over interpretation of faith; thus, social media has become a space where non-MUI religious individuals are taking a lead on discussions (Solahudin and Fakhruroji 2020). Salafism and its rivals have also presented themselves on social media and the internet at large where clashes regarding the conception of the 'ideal citizen' between subgroups are common (Sunarwoto 2021).

The 2019 presidential election was the first media-savvy election where the distribution and consumption of discourse were significantly determined by digital platforms (Santoso et al. 2020, p. 116). From the public space to social media, "the use of religious language and symbols in the political rhetoric has occupied not only existential public sphere but also virtual public sphere. At this level, emotional aspect of our human capacity could easily be manipulated for partial political purposes" (Wijanarko 2021). With the increasingly authoritarian stance taken by the government, coupled with a muffled space for religious deviance from MUI's stance, Indonesian politics in the absence of a vibrant civil society has seen the facilitation of religious populism on social media that mimics the ground realties of the country (Wijanarko 2021; Santoso et al. 2020).

In a non-religious context as well, populism has surfaced in the social media of Indonesian users. A study on the 2019 presidential campaign using content analysis of political campaigns on social media showed that "infrastructure, food, energy, and radical" were the main key themes of discussion for the duos of Prabowo-Sandi and Jokowi-Ma'ruf (Santoso et al. 2020).

Populist polarisation reached a new zenith in the 2019 presidential election, when Jokowi and Prabowo faced off again. Prabowo's campaign again depicted Jokowi as a threat to the ummah (Warburton 2020, p. 28). This time, the Jokowi campaign went on the offensive and employed an equally polarising narrative, claiming that Prabowo's victory would lead to an Islamic caliphate that would threaten the essence of Indonesia's pluralist national identity (Warburton 2020, p. 28). During this election, politicians hired social media campaigners to produce disinformation about their opponent (Tapsell 2020, p. 14). Cyberspace, regardless of the type of platform, became a kind of mood booster so that people's emotions never subsided (Khoiri et al. 2021, p. 8). YouTube, Facebook, and Twitter were full of content that become the gateway to the rival populist groups (Khoiri et al. 2021, p. 18). 


\section{Concluding Remarks}

Clearly, Indonesia has witnessed significant recent growth in populist politics. This increase has had several negative impacts on the state of democracy as well as on the social balance in society. Populism has diversified in the context of Indonesia, where it has taken various forms to meet the needs of different groups. What is more worrying is the ability of one form of populism to absorb the attributes and ideologies from others and hybridise. This hybridisation process is evident in the populism of both Jokowi and Prabowo. While Prabowo's populism is a hotchpotch of populist rhetoric (featuring authoritarianism, anti-political elite, anti-corruption, etc.), the recent adoption of Islamist ideals since the anti-Ahok protests has damaged the intricate balance of heterogeneity within Indonesian society. Chinese-Catholics have repeatedly been targeted in Indonesia, and the anti-Ahok campaign illustrated the pre-existing vulnerability in its society. Prabowo has used the Chinese community as a scapegoat to add to a list of the 'otherised' while adding to the trauma, insecurities, and plights of 'the pious'. This merger of chauvinistic populism with right-wing Islamism has made an opening for Islamism in Indonesian politics, which had previously avoided the mainstreaming of conservatism in society.

At the other end of the spectrum, the absorptive capacity of Jokowi's populism poses a challenge of a different kind to Indonesian democracy. While it has tweaked its strategy by opening up to Islamic elements in its politics, the most profound implications are the transformation of 'lite-populism' to creeping authoritarianism. The use of constitutional populism and penal populism has given Jokowi's second presidency a more authoritarian aspect. The constant political compromises with the political elite and adjustments made to accommodate and pacify opposition, when combined with authoritarianism, have made the environment in Indonesia highly conducive to grass roots oppositions, unwilling to compromise for opposition groups and civil society. In the long-term, this constant encroachment of rights and freedoms is only feeding marginalisation and divisions in Indonesia. For instance, the ban on FPI has been seen by many to represent a politically motivated move by the government. At the same time, it has alienated members of FPI and has risked driving them towards more extreme forms of Islamism. At the same time, Jokowi has established a precedent of revival of the military tradition era of instrumentalising state institutions such as the security forces, media outlets, and office of the attorney general to further its position in power.

While the existence of populism and its variants in the world's largest Muslim country is worrying enough, the social and political realities of the political world are being replicated in cyberspace as well. This study has shown that this mirroring of populism has helped Islamists and non-Islamist populists enhance their presence and rhetoric with the help of cyberspace activities. The replication of this negativity only helps increase the feeling of isolation and abandonment felt by 'the people' and has given fuel to the 'otherisation' process. This enhanced impact of cyber populism is worrying because there is a fear of further disillusionment of the public with the political system when the populists fail to live up to their promises. The case of Jokowi demonstrates the consequences of growing disillusionment with populist leaders. Jokowi came to power as a 'lite-populist' and his failure to live up to campaign promises combined with the growing counter populism and compromises with the elite led him to adopt harsher streams of populism. The 2024 elections will be critical for Indonesia as Jokowi's second term has been plagued with resentful feelings towards the government, which open a doorway for either total disillusion with the electoral process or for a new populist leader. In both situations, the democratic order of the country suffers.

While each populist actor has their own ideology, each shares the pattern of dichotomising society into the 'in' and 'out' group categories, and they effectively use cyberspace for this purpose. In a society where economic and social divides are prevalent, the added burden of populist politics is a worrying development. While mainstream political parties remain relatively immune from populism, they have cooperated and hosted populists for their own survival in power. It is unclear how long this populist spree will last 
in Indonesia; however, it will take a lot of effort and commitment to undo the regression of this period and its damaging effects to democratic institutions and the societal fabric.

Author Contributions: Conceptualization, I.Y.; methodology, I.Y.; writing-original draft preparation, I.Y. and G.B.; writing-review and editing, I.Y. and G.B.; project administration, I.Y. All authors have read and agreed to the published version of the manuscript.

Funding: This research received no external funding.

Data Availability Statement: Not applicable.

Conflicts of Interest: The authors declare no conflict of interest.

\section{References}

Adiwilaga, Rendy, Mustabsyirotul Ummah Mustofa, and Muhammad Ridha Taufik Rahman. 2019. Quo Vadis Islamic Populism? An Electoral Strategy. Central European Journal of International and Security Studies 13: 432-53.

Amal, M. Khusna. 2020. Islamic populism in Southeast Asia: An Indonesian Muslim intellectuals perspective. Journal of Critical Reviews 7: 583-88.

Arifianto, R. Alexander. 2019. Is Islam an increasingly polarizing political cleavage in Indonesia? Brookings. Available online: https:/ / www.brookings.edu/blog/order-fromchaos/2019/04/25/is-islam-an-increasingly-polarizing-political-cleavagein-indonesia/ (accessed on 25 August 2021).

Aspinall, Edward. 2015. Oligarchic Populism: Prabowo Subianto's Challenge to Indonesian Democracy. Indonesia 99: 1-28. [CrossRef]

Bartlett, Jamie. 2018. The People vs Tech: How the Internet Is Killing Democracy (and How We Save It). New York: Random House.

Barton, Greg, Matteo Vergani, and Yenny Wahid. 2021a. Santri with attitude: Support for terrorism and negative attitudes to non-Muslims among Indonesian observant Muslims. Behavioral Sciences of Terrorism and Political Aggression, 1-15. [CrossRef]

Barton, Greg, Paul Weller, and Ihsan Yilmaz. 2013. The Muslim World and Politics in Transition: Creative Contributions of the Gülen Movement. London and New York: Bloomsbury Publishers.

Barton, Greg, Yilmaz Ihsan, and Morieson Nicholas. 2021b. Religious and Pro-Violence Populism in Indonesia: The Rise and Fall of a Far-Right Islamist Civilisationist Movement. Religions 12: 397. [CrossRef]

Barton, Greg, Yilmaz Ihsan, and Morieson Nicholas. 2021c. Authoritarianism, Democracy, Islamic Movements and Contestations of Islamic Religious Ideas in Indonesia. Religions 12: 641. [CrossRef]

Barton, Greg. 2002. Abdurrahman Wahid: Muslim Democrat, Indonesian President; a View from the Inside. Honolulu: University of Hawaii Press.

Barton, Greg. 2005. Jemaah Islamiyah: Radical Islamism in Indonesia. Singapore: NUS Pres.

Barton, Greg. 2006. Islam and Democratic Transition in Indonesia. In Religious Organizations and Democratization: Case Studies from Contemporary Asia. Edited by Deborah A. Brown and Tun-Jen Cheng. New York: M. E. Sharpe, chp. 9. pp. 221-41.

Barton, Greg. 2010a. Guide to Islamist Movements. Edited by Barry Rubin. New York: M. E. Sharpe, Inc.

Barton, Greg. 2010b. Indonesia: Legitimacy, secular democracy, and Islam. Politics E Policy 38: 471-96.

Barton, Greg. 2021. Contesting Indonesia's Democratic Transition: Laskar Jihad, the Islamic Defenders Front (FPI) and Civil Society. In Security, Democracy, and Society in Bali. Edited by Andrew Vandenberg and Nazrina Zuryani. Singapore: Palgrave Macmillan, chp. 13. pp. 305-31. Available online: https://www.springerprofessional.de/en/contesting-indonesia-s-democratic-transitionlaskarjihad-the-is/18440394 (accessed on 25 August 2021).

Berezin, Mabel. 2016. It's Time to Admit It: We're All Afraid of Terrorism-And That's the Entire Point of It. Salon. July 22. Available online: https://www.salon.com/2016/07/22/its_time_to_admit_it_were_all_afraid_of_terrorism_and_thats_the_ entire_point_of_it_partner/ (accessed on 25 August 2021).

Bland, Ben. 2019. How President Joko Widodo Is Eroding Indonesia's Democracy. Italian Institute for Insertional Political Studies. Available online: https:/ / www.ispionline.it/en/pubblicazione/how-president-joko-widodo-eroding-indonesias-democracy24587 (accessed on 25 August 2021).

Bland, Ben. 2020. The (un)making of Joko Widodo. The Interpreter. Available online: https:/ / www.lowyinstitute.org/the-interpreter/ unmaking-joko-widodo (accessed on 25 August 2021).

Bracciale, Roberta, and Antonio Martella. 2017. Define the populist political communication style: The case of Italian political leaders on Twitter. Information, Communication \& Society 20: 1310-29.

Buštíkovà, Lenka, and Petra Guasti. 2018. The State as a Firm: Understanding the Autocratic Roots of Technocratic Populism. East European Politics and Societies and Cultures 33: 302-30. [CrossRef]

Campos, María José Salcedo. 2021. Is Democracy in the Hands of Social Media? A Liberal Perspective on Populism, Social Media and Free Press. Potsdam: The Friedrich Naumann Foundation for Freedom.

Chew, Amy. 2019. Indonesia's Largest Muslim Group Set for Bigger Role in Jokowi's Second Term. This Week in Asia. August 2. Available online: https:/ /www.scmp.com/weekasia/politics/article/3021124/indonesias-largest-muslim-group-set-biggerrole-jokowis-second (accessed on 25 August 2021). 
Conrad, Maximilian. 2021. Post-Truth Politics, Digital Media, and the Politicization of the Global Compact for Migration. Politics and Governance 9: 301-11. [CrossRef]

De Cleen, Benjamin, and Yannis Stavrakakis. 2017. Distinctions and Articulations: A Discourse Theoretical Framework for the Study of Populism and Nationalism. Javnost: The Public 24: 301-19. [CrossRef]

De la Torre, Carlos, ed. 2019. Routledge Handbook of International Populism. New York and Oxen: Routledge.

Engesser, Sven, Nicole Ernst, Frank Esser, and Florin Büchel. 2017. Populism and social media: How politicians spread a fragmented ideology. Information, Communication \& Society 20: 1109-26. [CrossRef]

Enli, Gunn. 2017. Twitter as arena for the authentic outsider: Exploring the social media campaigns of Trump and Clinton in the 2016 US presidential election. European Journal of Communication 32: 50-61. [CrossRef]

Epley, Jennifer, and Eunsook Jung. 2016. Vertically Disconnected: The Politics of Islam in Democratic Indonesia. Asian Journal of Social Science 44: 54-77. [CrossRef]

Fealy, Greg, and Robin Bush. 2014. The Political Decline of Traditional Ulama in Indonesia: The State, Umma and Nahdlatul Ulama. Asian Journal of Social Science 42: 536-60. [CrossRef]

Federspiel, Howard. 1991. Muslim Intellectuals and Indonesia's National Development. Asian Survey 31: 232-46. [CrossRef]

Feillard, Andrée. 2013. Nahdlatul Ulama in Indonesia. In The Oxford Handbook of Islam and Politics. Edited by John L. Esposito and Emad El-Din Shahin. New York: Oxford University Press. [CrossRef]

Fossati, Diego, and Marcus Mietzner. 2019. Analyzing Indonesia's Populist Electorate. Asian Survey 59: 769-94. [CrossRef]

Fukuoka, Yuki. 2013. Oligarchy and Democracy in Post-Suharto Indonesia. Political Studies Review 11: 52-64. Available online: https://www.researchgate.net/publication/275075301_Oligarchy_and_Democracy_in_Post-Suharto_Indonesia (accessed on 25 August 2021). [CrossRef]

Genta, Kuno Yoseph, and Wihartano. 2018. Reconfiguring Post-Ahok Populism, Post-Truth, and Cyberspace in Indonesia. Paper presented at 4th International Conference on Contemporary Social and Political Affairs (ICoCSPA), Surabaya, Indonesia, August 13; pp. 47-58.

Gerbaudo, Paolo. 2018. Social media and populism: An elective affinity? Media, Culture E Society 40: 745-53.

Guerrero-Solé, Frederic, Sara Suárez-Gonzalo, Cristòfol Rovira, and Lluís Codina. 2020. Social media, context collapse and the future of data-driven populism. Profesional de la información 29: e290506. [CrossRef]

Hadiz, Vedi. 2016. Islamic Populism in Indonesia and the Middle East. Cambridge: Cambridge University Press.

Hara, Abubakar, Aman, and Nuzon Sugito. 2019. Strategy of Prabowo Populism in 2019 General Elections. Advances in Social Science, Education and Humanities Research 398: 20-23.

Hara, Abubakar. 2017. Populism in Indonesia and its Threats to Democracy. Advances in Social Science, Education and Humanities Research 129: 106-11.

Hara, Abubakar. 2019. The Failure of Islamic Populism in Indonesia's 2019 Election. Advances in Social Science, Education and Humanities Research 339: 259-63.

Hendrickson, Clara, and William Galston. 2017. Why are populists winning online? Social media reinforces their anti-establishment message. Brookings. April 28. Available online: https://www.brookings.edu/blog/techtank/2017/04/28/why-are-populistswinning-online-social-media-reinforces-their-anti-establishment-message/ (accessed on 25 August 2021).

Hoover, Stewart. 2006. Religion in the Media Age, 1st ed. London and New York: Routledge.

Jati, Wasisto. 2013. Radicalism in the perspective of Islamic-Populism Trajectory of Political Islam in Indonesia. Journal of Indonesian Islam 7: 268-87. [CrossRef]

Johansson, Anders. 2016. Social Media and Politics in Indonesia. Stockholm School of Economics Asia Working Paper 42: 1-45.

Khoiri, Ahmad, Faizi, and Jindar Muttaqin. 2021. The Transmission of Islamic Populism and Extremist Ideology through Social Media in Indonesia. Jurnal Tashwirul Afkar 40: 1-21.

Klinger, Ulrike, and Jakob Svensson. 2015. The emergence of network media logic in political communication: A theoretical approach. New Media and Society 17: 1241-57. [CrossRef]

Krämer, B. 2017. Populist online practices: The function of theInternet in right-wing populism. Information, Communication $\mathcal{E}$ Society 20: 1293-309.

Kreis, Ramona. 2017. The "tweet politics" of president Trump. Journal of Language and Politics 16: 607-18. [CrossRef]

Kriesi, Hanspeter. 2014. The populist challenge. West European Politics 37: 361-78. [CrossRef]

Laclau, Ernesto. 2005. On Populist Reason. London and New York: Verso.

Leslie, Palmier. 1957. Sukarno, the Nationalist. Pacific Affairs 30: 101-19. [CrossRef]

Levinson, Paul. 2020. Fake News: Understanding Media and Misinformation in the Digital Age. Edited by Melissa Zimdars and Kembrew McLeod. Cambridge and London: The MIT Press.

Lim, Merlyna. 2013. Many Clicks but Little Sticks: Social Media Activism in Indonesia. Journal of Contemporary Asia 43: 636-57. [CrossRef]

Lim, Merlyna. 2015. Many Clicks but Little Sticks: Social Media Activism in Indonesia. In Digital Activism in Asia Reader. Edited by Nishant Shah, Puthiya Purayil Snehaa and Sumandro Chattapadhyay. Lüneburg: Meson Press, pp. 127-54.

Lim, Merlyna. 2017. Freedom to hate: Social media, algorithmic enclaves, and the rise of tribal nationalism in Indonesia. Critical Asian Studies 49: 1-17. [CrossRef] 
Machmudi, Yon. 2008. Islamising Indonesia: The Rise of Jemaah Tarbiyah and the Prosperous Justice Party (PKS). Canberra: ANU Press. Available online: http:/ / www.jstor.org/stable/j.ctt24hddh (accessed on 25 August 2021).

Mietzner, Marcus. 2015. Reinventing Asian Populism: Jokowi's Rise, Democracy, and Political Contestation in Indonesia. Policy Studies 72: $1-74$.

Mietzner, Marcus. 2018. Fighting Illiberalism with Illiberalism: Islamist Populism and Democratic Deconsolidation in Indonesia. Pacific Affairs 91: 261-82. [CrossRef]

Mietzner, Marcus. 2020. Rival populisms and the democratic crisis in Indonesia: Chauvinists, Islamists and technocrats. Australian Journal of International Affairs 74: 420-38. [CrossRef]

Miichi, Ken. 2014. The Role of Religion and Ethnicity in Jakarta's 2012 Gubernatorial Election. Current Southeast Asian Affairs 33: 55-83. [CrossRef]

Moffitt, Benjamin. 2016. The Global Rise of Populism: Performance, Political Style, and Representation. Palo Alto: Stanford UP.

Mudde, Cas. 2004. The Populist Zeitgeist. Government and Opposition 39: 541-63. [CrossRef]

Muhtadi, Burhanuddin, and Kennedy Muslim. 2020. Populism, Islamism, and Democratic Decline in Indonesia. The Middle East Institute. August 4. Available online: https:/ /www.mei.edu/publications/populism-islamism-and-democratic-declineindonesia (accessed on 25 August 2021).

Nadzir, Ibnu, and Ranny Rastati. 2020. Charisma and Social Media In Indonesian Politics. Jurnal Masyarakat dan Budaya 22: 177-96. [CrossRef]

Niam, Khoirun. 2010. The discourse of muslim intellectuals and 'ulama' in indonesia: A Historical Overview. Journal of Indonesian Islam 4: 287-316. [CrossRef]

Nilan, Pam, and Gregorius Wibowanto. 2021. Challenging Islamist Populism in Indonesia through Catholic Youth Activism. Religions 12: 395. [CrossRef]

Nuryanti, Sri. 2021. Populism in Indonesia: Learning from the 212 Movement in Response to the Blasphemy Case against Ahok in Jakarta. In Populism in Asian Democracies. Edited by Sook Jong Lee, Chin-en Wu and Kaustuv Kanti Bandyopadhyay. Boston: Brill. Oxfam.

Permata, Ahmad-Norma. 2008. Ideology, institutions, political actions: Prosperous Justice Party (PKS) in Indonesia. ASIEN 109: 22-36. Available online: https://www.researchgate.net/publication/237780835_Ideology_institutions_political_actions_Prosperous_ Justice_Party_PKS_in_Indonesia (accessed on 25 August 2021).

PKB. 2014. Partai Kebangkitan Bangsa (PKB) (National Awakening Party) Indonesia. 2009. Translated for the Islamic Political Party Platform Project, University of North Carolina, Chapel Hill. Available online: http://kurzman.unc.edu/islamic-parties (accessed on 25 August 2021).

Postill, John. 2018. Populism and social media: A global perspective. Media, Culture E Society 40: 754-65.

Power, Tom. 2018. Jokowi's authoritarian turn. New Mandala. October 9. Available online: https:/ /www.newmandala.org/jokowisauthoritarian-turn/ (accessed on 25 August 2021).

Rooduijn, Matthijs. 2015. The rise of the populist radical right in Western Europe. European View 14: 3-11. [CrossRef]

Santoso, Didik Haryadi, Jamaluddin Aziz, Prahastiwi Utari, and Drajat TriKartono. 2020. Populism in New Media: The Online Presidential Campaign Discourse in Indonesia. Journal of Language Studies 20: 115-33. [CrossRef]

Satrio, Abdurrachman. 2019. A Battle Between Two Populists: The 2019 Presidential Election and the Resurgence of Indonesia's Authoritarian Constitutional Tradition. Australian Journal of Asian Law 19: 175-95.

Schäfer, Saskia. 2019. Democratic Decline in Indonesia: The Role of Religious Authorities. Pacific Affairs 92: 235-55. [CrossRef]

Shakil, Kainat, and Ihsan Yilmaz. 2021. Religion and Populism in the Global South: Islamist Civilisationism of Pakistan's Imran Khan. Religions 12: 777. [CrossRef]

Shils, Edward. 1956. The Torment of Secrecy: The Background and Consequences of American Security Policies. Glencoe: The Free Press.

Siuda, Piotr. 2021. Mapping Digital Religion: Exploring the Need for New Typologies. Religions 12: 373. [CrossRef]

Solahudin, Dindin, and Moch Fakhruroji. 2020. Internet and Islamic Learning Practices in Indonesia: SocialMedia, Religious Populism, and Religious Authority. Religions 11: 19. [CrossRef]

Sub, Jiwon. 2016. The Suharto Case. Asian Journal of Social Science 44: 214-45. Available online: http://www.jstor.org/stable/43953988 (accessed on 1 October 2020).

Suiter, Jane, Eileen Culloty, Derek Greene, and Eugenia Siapera. 2018. Hybrid media and populist currents in Ireland's 2016 general election. European Journal of Communication 33: 396-412. [CrossRef]

Sunarwoto. 2021. Online Salafi rivalries in Indonesia: Between sectarianism and 'good' citizenship. Religion, State E Society 49: 157-73. [CrossRef]

Tadjoeddin, Mohammad Zulfan. 2019. Inequality and Exclusion in Indonesia: Political Economic Developments in the Post-Soeharto Era. Journal of Southeast Asian Economies 36: 284-303. Available online: www.jstor.org/stable/26842377 (accessed on 25 August 2021). [CrossRef]

Taggart, Paul. 2002. Populism and the pathology of representative politics. In Democracies and the Populist Challenge. Edited by Yves Mény and Yves Surel. Basingstoke: Palgrave, pp. 62-80.

Tapsell, Ross. 2017. Media Power in Indonesia: Oligarchs, Citizens and the Digital Revolution. London: Rowman and Littlefield.

Tapsell, Ross. 2018. Disinformation and Democracy. New Mandala. January 12. Available online: https://www.newmandala.org/ disinformation-democracy-indonesia/ (accessed on 25 August 2021). 
Tapsell, Ross. 2020. Deepening the Understanding of Social Media's Impact in Southeast Asia. Singapore: ISEAS.

Temby, Quinton. 2020. The Elusive Pragmatist Who Transformed Political Islam in Indonesia. The Interpreter. Available online: https:/ / www.lowyinstitute.org/the-interpreter/elusive-pragmatist-who-transformed-political-islam-indonesia (accessed on 25 August 2021).

Tomsa, Dirk. 2019. Islamism and Party Politics in Indonesia. Oxford Research Encyclopedia of Politics. Available online: https:/ /oxfordre. com/politics/view/10.1093/acrefore/9780190228637.001.0001/acrefore-9780190228637-e-1157 (accessed on 25 August 2021).

Tong, Jingrong, and Landong Zuo. 2020. Mainstreaming populism through the Twitter practices of politicians and the news media: A case study of the 2016 Brexit referendum debates. Information Polity 25: 361-75. [CrossRef]

Vosoughi, Sorous, Deb Roy, and Sinan Aral. 2018. The spread of true and false news online. Science 359: 1146-51. [CrossRef] [PubMed]

Vreese, Claes, Frank Esser, Toril Aalberg, Carsten Reinemann, and James Stanyer. 2018. Populism as an expression of political communication content and style: A new perspective. The International Journal of Press/Politics 23: 423-38. [CrossRef] [PubMed]

Warburton, Eve. 2020. Deepening Polarization and Democratic Decline in Indonesia. In Political Polarization in South and Southeast Asia Old Divisions. Edited by Thomas Carothers, Andrew O'Donohue and New Dangers. New York: Carnegie, pp. 25-40.

Weyland, Kurt. 2001. Clarifying a Contested Concept: Populism in the Study of Latin American Politics. Comparative Politics 34: 1-22. [CrossRef]

Wijanarko, Robertus. 2021. Religious Populism and Public Sphere in Indonesia. Jurnal Sosial Humaniora, 1-9. [CrossRef]

Yilmaz, Ihsan, and Greg Barton. 2021a. Populism, Violence, and Vigilantism in Indonesia: Rizieq Shihab and His Far-Right Islamist Populism. Brussels: European Center for Populism Studies. Available online: https:/ /www.populismstudies.org/populism-violence-andvigilantism-in-indonesia-rizieq-shihab-and-his-far-right-islamist-populism/ (accessed on 25 August 2021).

Yilmaz, Ihsan, and Greg Barton. 2021b. The Islamic Defenders Front: The Face of Indonesia's Far-Right Islamism. Brussels: European Center for Populism Studies. Available online: https:/ / www.populismstudies.org/the-islamic-defenders-front-the-face-of-indonesiasfar-right-islamism/ (accessed on 25 August 2021).

Yilmaz, Ihsan, and Nicholas Morieson. 2021. A Systematic Literature Review of Populism, Religion and Emotions. Religions 12: 272. [CrossRef]

Yilmaz, Ihsan, Mustafa Demir, and Nicholas Morieson. 2021a. Religion in Creating Populist Appeal: Islamist Populism and Civilizationism in the Friday Sermons of Turkey's Diyanet. Religions 12: 359. [CrossRef]

Yilmaz, Ihsan, Nicholas Morieson, and Mustafa Demir. 2021b. Exploring Religions in Relation to Populism: A Tour around the World. Religions 12: 301. [CrossRef]

Yilmaz, Ihsan. 2020. Populism Profile: Indonesia. Brussels: European Center for Populism Studies. Available online: https://www. populismstudies.org/tag/indonesia/ (accessed on 25 August 2021).

Zarkasyi, Fahmi Hamid. 2008. The rise of Islamic religious-political movements in Indonesia: The background, present situation and future. Journal of Indonesian Islam 2: 336. [CrossRef]

Zulianello, Mattia, Allesandro Albertini, and Diego Ceccobelli. 2018. A populist zeitgeist? The communication strategies of Western and Latin American political leaders on Facebook. The International Journal of Press/Politics 23: 439-57. [CrossRef] 